\title{
Expression, biosynthesis and release of preadipocyte factor-1/ delta-like protein/fetal antigen-1 in pancreatic $\beta$-cells: possible physiological implications
}

\author{
B N Friedrichsen ${ }^{1,2}$, C Carlsson ${ }^{1,4}$, A Møldrup ${ }^{1,2}$, B Michelsen ${ }^{1}$, \\ C H Jensen ${ }^{3}$, B Teisner ${ }^{3}$ and J H Nielsen ${ }^{1,5}$ \\ ${ }^{1}$ Hagedorn Research Institute, Gentofte, Denmark \\ ${ }^{2}$ Department of Islet Discovery, Novo Nordisk A/S, Bagsværd, Denmark \\ ${ }^{3}$ Department of Immunology and Microbiology, University of Southern Denmark, Odense, Denmark \\ ${ }^{4}$ Department of Medical Cell Biology, University of Uppsala, Sweden \\ ${ }^{5}$ Department of Medical Biochemistry and Genetics, University of Copenhagen, Denmark \\ (Requests for offprints should be addressed to B N Friedrichsen, Department of Islet Discovery Research, Novo Nordisk A/S, Novo Alle 1, 1KM.04, \\ DK-2880 Bagsværd, Denmark; Email: bttm@novonordisk.com)
}

\begin{abstract}
Preadipocyte factor-1 (Pref-1)/delta-like protein/fetal antigen-1 (FA1) is a member of the epidermal growth factor-like family. It is widely expressed in embryonic tissues, whereas in adults it is confined to the adrenal gland, the anterior pituitary, the endocrine pancreas, the testis and the ovaries. We have previously cloned Pref- 1 from neonatal rat islets stimulated by GH. The aim of the present study was to elucidate the biosynthesis and release of Pref-1/FA1 in $\beta$-cells and to determine if Pref-1/FA1 is mediating the mitogenic effect of GH in insulinproducing cells. First we studied the biosynthesis and processing of Pref- 1 to the soluble form, FA1, in pancreatic islets and insulinoma cells transfected with Pref-1 cDNA. We measured the release of FA1 by ELISA and the possible effect of FA1 in GH-stimulated $\beta$-cell proliferation by incorporation of bromodeoxyuridine (BrdU) in insulin-positive islet cells. We found that Pref-1 was synthesized in normal islets and in RINm5F insulinoma cells and released into the medium in two forms, of which one corresponded to FA1. Both the expression of the
\end{abstract}

mRNA for Pref-1 and the release of the soluble form(s) were stimulated by GH and prolactin (PRL). Whereas $2 \mathrm{~h}$ exposure to high glucose or 3-isobutyl-1-methylxanthine stimulated insulin release, only a small change was seen in FA1 release, suggesting that the FA1 is released by a different pathway than insulin. However, long-term exposure $(48 \mathrm{~h})$ to high glucose increased FA1 secretion, indicating that FA1 is regulated by glucose. Neither FA1 nor conditioned medium from GH-stimulated islets depleted for GH was able to increase $\beta$-cell replication and overexpression of Pref-1 resulted in attenuated proliferation of the RINm5F cells. By immunocytochemistry of $\mathrm{GH}$-stimulated islet cells no correlation between high Pref-1 expression and BrdU incorporation was observed and there was an inverse relationship between the levels of insulin and Pref-1. These results indicate that Pref-1/FA1 is not mediating the mitogenic effect of GH and PRL. Therefore the function of Pref- 1 in the $\beta$-cell remains unknown.

Journal of Endocrinology (2003) 176, 257-266

\section{Introduction}

Preadipocyte factor-1 (Pref-1)/delta-like protein, a member of the epidermal growth factor (EGF)-like family, was first cloned from the mouse preadipocyte cell line 3T3-L1 (Smas \& Sul 1993) and the adrenal gland and certain neuroendocrine tumours (Laborda 2000). Pref-1 was also cloned using differential screening of a cDNA library from growth hormone $(\mathrm{GH})$-stimulated rat islets of Langerhans (Carlsson et al. 1997) and by subtraction cloning strategies from a murine primitive haematopoietic cell line (Moore et al. 1997) and rat adrenal cortex (Okamoto et al. 1998).
Pref- 1 is a transmembrane protein of 383 amino acids (aa) that contains six tandem EGF-like repeats and a signal sequence in the extracellular domain (Smas \& Sul 1993). The extracellular part of Pref-1 corresponds to the soluble protein, fetal antigen-1 (FA1), originally isolated from second trimester normal human amniotic fluid (Fay et al. 1988). FA1 may be formed by proteolytic cleavage of Pref- 1 and/or by alternative mRNA splicing (Smas et al. 1997).

The expression pattern of Pref-1/FA1 has been studied by immunohistochemistry in different tissues. In the adult, Pref-1/FA1 expression is limited to the zona glomerulosa 
of the adrenal gland (Jensen et al. 1993), the $\beta$-cells in the endocrine pancreas (Tornehave et al. 1993, 1996), the somatotrophs in the pituitary gland (Larsen et al. 1996), the monoaminergic neurons in the central nervous system (Jensen et al. 2001), and the Leydig and hilus cells of the testes and ovaries (Floridon et al. 2000). In the fetus, Pref-1/FA1 is widely expressed in, for example, liver, tongue, vertebrae, skeletal myotubes, chondroblasts (Tornehave et al. 1989, Smas \& Sul 1993, Floridon et al. 2000) and pancreas (embryonic day E13-E16), in which it is localized to most of the pancreatic parenchymal cells but later in the development (from E19) it becomes restricted to the $\beta$-cells of the islets of Langerhans as well as to small islet-like clusters (Carlsson et al. 1997).

The function of Pref-1/FA1 is not known. It is unlikely that Pref-1/FA1 binds to the EGF receptor as none of the six EGF-like repeats contains the same spacing of cysteine and other aa crucial for binding to the EGF receptor. The cysteine spacing and aa sequence within the individual EGF-like domains of Pref-1 are more similar to those of the Drosophila protein Delta (Smas \& Sul 1993), which is a transmembrane protein with nine EGF-like repeats and a cysteine-rich motif termed DSL (Delta-Serrate-Lag 2) in the extracellular domain. The DSL region appears to be important for its binding to the Notch receptor (ArtavanisTsakonas et al. 1995). However, the DSL motif is absent from Pref-1, indicating that Pref-1/FA1 is an unlikely ligand for Notch. Both in primary preadipocytes and in 3T3-L1 cells, Pref-1 was found to be abundant in the undifferentiated proliferating state and profoundly downregulated during adipocyte differentiation. Furthermore, constitutive expression of Pref-1 in 3T3-L1 cells as well as treatment of these cells with exogenous recombinant mouse FA1 was found to inhibit differentiation (Smas \& Sul 1993). This effect has been confirmed in our laboratory, where the differentiation of primary rat preadipocytes was found to be inhibited in a dose-dependent manner by human FA1 (hFA1) (Hansen et al. 1998).

In the $\beta$-cells, Pref- 1 was found to be upregulated by the pituitary hormones GH and prolactin (PRL) (Carlsson et al. 1997). These hormones stimulate insulin biosynthesis as well as proliferation of the pancreatic $\beta$-cells (Nielsen 1982, Brelje et al. 1993, Sorenson \& Brelje 1997) and insulinoma cell lines (Billestrup \& Martin 1985, Sekine et al. 1996). The mechanism of this proliferative response is not known but it could involve induction of autocrine growth factors or activation of a certain stem cell-like population. GH/PRL-stimulated production of insulinlike growth factor-I (IGF-I) has been excluded as a mediator of the mitogenic effect in both primary $\beta$-cells (Billestrup \& Nielsen 1991) and the insulinoma cell line, INS-1 (De et al. 1995). In adipocytes (Smas \& Sul 1993), adrenals (Okamoto et al. 1998), and stromal cells supporting haematopoietic cells (Moore et al. 1997), Pref-1 seems to be a factor which acts as a so-called inverted differentiation factor, the role of which is to maintain a population of undifferentiated, possibly proliferating, stem cells. Whether Pref-1/FA1 could play a similar role in the islets has not previously been addressed. Alternatively, secreted FA1 could act as a local growth factor for the $\beta$-cells. In the present report, we describe the regulation of synthesis and expression of Pref-1/FA1 by GH, PRL and glucose in neonatal rat pancreatic islets. In addition we show that neither exogenous nor endogenous FA1 exerts a mitogenic effect on $\beta$-cells in monolayer culture and that expression of Pref-1/FA1 in a subpopulation of $\beta$-cells does not correlate with mitogenic activity.

\section{Materials and Methods}

\section{Islets, cells and hormones}

Islets from neonatal (days 2-6) Wistar-Furth rats (Taconic M\&B A/S, Ry, Denmark), handled according to the Danish Act For Experimental Animals, were isolated by the collagenase digestion method (Brunstedt et al. 1984) and cultured until further processing in RPMI 1640 supplemented with $10 \%$ newborn calf serum, $100 \mathrm{U} / \mathrm{ml}$ penicillin, $100 \mu \mathrm{g} / \mathrm{ml}$ streptomycin, $2 \mathrm{mM}$ L-glutamine, $0.0375 \% \mathrm{NaHCO}_{3}$ and $20 \mathrm{mM}$ Hepes at $37^{\circ} \mathrm{C}$ in a humidified atmosphere. Conditioned medium was made by culturing 2000 islets in $15 \mathrm{ml}$ RPMI $1640+2 \%$ human serum (HS) $\pm 0 \cdot 2 \mu \mathrm{g} / \mathrm{ml}$ human $\mathrm{GH}(\mathrm{hGH})$ for 2 days. The islets were sedimented at $100 \mathrm{~g}$ and medium was collected for further use. Human islets (obtained from the $\beta$-cell Transplant Centre, Free University, Brussels) were cultured in RPMI $1640+0 \cdot 5 \%$ HS. RINm5F rat insulinoma cells were cultured in RPMI 1640 containing $10 \%$ fetal calf serum (FCS), $100 \mathrm{U} / \mathrm{ml}$ penicillin and $100 \mu \mathrm{g} / \mathrm{ml}$ streptomycin at $37^{\circ} \mathrm{C}$ in a humidified atmosphere containing $5 \% \mathrm{CO}_{2}$. Recombinant hGH was obtained from Novo Nordisk A/S (Bagsværd, Denmark), bovine $\mathrm{GH}(\mathrm{bGH})$ from Biogenesis (Poole, UK), ovine PRL (oPRL) from Sigma, and hFA1 from B Teisner, University of Southern Denmark.

\section{Transfection of RINm5F cells with human Pref-1 (hPref-1)}

Eighteen microlitres of Lipofectamine (Gibco BRL, Gaithersburg, MD, USA) were diluted with water to a final volume of $100 \mu \mathrm{l}$ and then gently mixed with an equal volume of water containing $1 \mu \mathrm{g}$ full-length hPref-1 cDNA in the pcDNA/neo vector, or as control $1 \mu \mathrm{g}$ pcDNA 3/neo. The solutions were incubated for $45 \mathrm{~min}$ at room temperature (RT) and then added to RINm5F cells (passage number $>120$ ) during $5 \mathrm{~h}$ at $37^{\circ} \mathrm{C}$ in culture medium RPMI 1640 containing $2 \mathrm{mM}$ L-glutamine. After transfection, 10\% FCS, $100 \mathrm{U} / \mathrm{ml}$ benzoylpenicillin and $0.1 \mathrm{mg} / \mathrm{ml}$ streptomycin were added and $24 \mathrm{~h}$ later $150 \mu \mathrm{g} / \mathrm{ml}$ geneticin (Sigma) to induce selection of 
transfected clones. The proliferation rate was evaluated by plating 30000 cells in 24-well plates and culturing them for $96 \mathrm{~h}$ in RPMI 1640. Cell counts were performed every $24 \mathrm{~h}$ in a Bürker chamber.

\section{Metabolic labelling and immunoprecipitation}

RINm5F stably transfected with full-length hPref-1 were seeded at $10^{6}$ cells $/ 60 \mathrm{~mm}$ dishes and cultured for $24 \mathrm{~h}$ in RPMI $1640+10 \%$ FCS followed by incubation for $20 \mathrm{~min}$ in RPMI 1640 without methionine/cysteine +2\% FCS. The cells were pulsed for $30 \mathrm{~min}$ with $0.4 \mathrm{mCi}$ Pro-mix $\left({ }^{35}\right.$ S-labelled methionine and cysteine, $\left.14.3 \mathrm{mCi} / \mathrm{ml}\right)$ (Amersham). Medium was changed to RPMI $1640+2 \%$ FCS and cells were chased for the indicated periods. Medium was collected for immunoprecipitation and cell monolayers were harvested in radioimmunoprecipitation assay (RIPA) buffer (PBS with 1\% NP40, $0.5 \%$ sodium deoxycholate, $0 \cdot 1 \%$ SDS, $1 \mu \mathrm{g} / \mathrm{ml}$ aprotonin, $1 \mu \mathrm{g} / \mathrm{ml}$ leupeptin, $1 \mathrm{mM} \quad 4$-(2-aminoethyl)benzenesulphonylfluoride hydrochloride, $1 \mathrm{mM}$ vanadate). The same was done for human islets using 1000 islets per chase and $2 \%$ HS instead of $2 \%$ FCS. For immunoprecipitation, equal amounts of sample (based on protein content) were incubated with $1 \mu \mathrm{g} / \mathrm{ml} \mathrm{R} \alpha \mathrm{hFA} 1$ (immunospecific affinity-purified rabbit anti-hFA1) (Jensen et al. 1993) and placed on a rotation device at $4{ }^{\circ} \mathrm{C}$ overnight. Immune complexes were collected by protein G-Sepharose (20\% ethanol) (Pharmacia Biotech) treatment for $1 \mathrm{~h}$. The Sepharose particles were washed three times in RIPA buffer (placed on ice between the washes). The complexes were diluted in $50 \mu \mathrm{l}$ sample buffer $(50 \mathrm{mM}$ Tris- $\mathrm{HCl}, 100 \mathrm{mM}$ dithiothreitol, 2\% SDS, $0 \cdot 1 \%$ bromophenol blue, $10 \%$ glycerol) and boiled before fractionation on SDS-PAGE gels. Exposure to X-ray film was made at $-80{ }^{\circ} \mathrm{C}$.

\section{RT-PCR}

Islets (600 islets $/ 4 \mathrm{ml}$ in $60 \mathrm{~mm}$ dishes) were cultured for either 4 or 7 days in RPMI 1640 supplemented with $2 \mathrm{mM}$ L-glutamine, $100 \mathrm{U} / \mathrm{ml}$ penicillin and $0.5 \% \mathrm{HS}$ in the absence or presence of either $1 \mu \mathrm{g} / \mathrm{ml} \mathrm{bGH}$ or $1 \mu \mathrm{g} / \mathrm{ml}$ oPRL.

Total RNA was extracted using the RNAzol (Biotech Laboratories, Austin, TX, USA) method, which is based on thiocyanate/phenol/chloroform extraction (Chomczynski \& Sacchi 1987). cDNA was synthesized from $1 \mu \mathrm{g}$ total RNA using M-MLV reverse transcriptase, random primers and dNTP mix from Life Technologies, Inc. The reaction was run at $37^{\circ} \mathrm{C}$ for $1 \mathrm{~h}$, and diluted in $30 \mu \mathrm{H}_{2} \mathrm{O}$ and stored at $-20^{\circ} \mathrm{C}$. For PCR the primer sequences were: Pref-1, 5' TCT GCG AGG CTG ACA ATG TCT GC (forward); 5' CCT TGT GCT GGC AGT CCT TTC C (reverse); glucose 6-phosphate dehydrogenase (G6PDH), 5' GAC CTG CAG AGC TCC AAT CAA C (forward); 5' CAC GAC CCT CAG TAC
CAA AGG G (reverse). The expected lengths were 275 and $214 \mathrm{bp}$ respectively. PCR was performed using $6 \%$ of the cDNA and $20 \mathrm{pmol} /$ primer in $1 \times$ PCR buffer, $5 \mu \mathrm{Ci}$ $\left[\alpha_{-}{ }^{33} \mathrm{P}\right] \mathrm{dCTP}, 4 \mathrm{mM}$ dCTP and $8 \mathrm{mM}$ dATP, dGTP, dTTP and 1.0 U DynaZyme DNA polymerase (Finnzymes Oy, Espoo, Finland). The reactions were run for $18-20$ cycles $\left(30 \mathrm{~s}\right.$ at $94{ }^{\circ} \mathrm{C}, 60 \mathrm{~s}$ at $55^{\circ} \mathrm{C}$ and $90 \mathrm{~s}$ at $72{ }^{\circ} \mathrm{C}$ ). The amplified products were separated on a $6 \%$ denaturating polyacrylamide gel (GEL-MIX 6; Life Technologies, Inc.), dried and exposed to a Phosphorimager storage screen overnight and analysed using the Image Quant program on the Phosphorimager series 400 (Molecular Dynamics, Inc., Sunnyvale, CA, USA). For quantification both amplicons were in the exponential amplification range.

\section{ELISA}

Islets were pre-cultured for 1 day in RPMI 1640 supplemented with $5.5 \mathrm{mM}$ glucose and $0.5 \% \mathrm{HS}$. Medium was changed to RPMI 1640 supplemented with $0.5 \%$ HS and either $3.3 \mathrm{mM}$ glucose or $16 \mathrm{mM}$ glucose. The islets were cultured for either $2 \mathrm{~h}$ (600 islets/ml) or 2 days (200 islets $/ 4 \mathrm{ml}$ ). Measurement of FA1 was performed as an antibody-capture assay using affinity-purified rabbit antimouse FA1 (RamFA1) as capture antibody (Bachmann et al. 1996). The assay was similar to that previously described (Bachmann et al. 1996, Jensen et al. 1997). Briefly, in each step, $100 \mu \mathrm{l}$ reagent /well were added and the plate was washed four times in washing buffer, $\mathrm{pH} 7 \cdot 4$ (PBS supplemented with 0.05\% Tween-20). NuncImmuno Plates Maxi Sorp F96 (Nunc, Roskilde, Denmark) were coated with RamFA1 $(0.13 \mathrm{mg} / \mathrm{ml})$ diluted $1: 300$ in carbonate buffer, $\mathrm{pH} \quad 9.6 \quad(15 \mathrm{mM}$ $\mathrm{Na}_{2} \mathrm{CO}_{3}$ and $34.9 \mathrm{mM} \mathrm{NaHCO}$ ) and incubation for $2 \mathrm{~h}$ at RT, followed by washing. Samples and calibrator (rat amniotic fluid in a dilution row) were incubated overnight. As detector, biotinylated RamFA1 antibody $(0 \cdot 86 \mathrm{mg} / \mathrm{ml})$ diluted $1: 3500$ in dilution buffer, $\mathrm{pH} 7 \cdot 4$ (PBS with $0.05 \%$ Tween-20 and $0.05 \%$ normal rabbit serum) was used. Peroxidase-conjugated streptavidin (Zymed, San Francisco, CA, USA), $\mathrm{H}_{2} \mathrm{O}_{2}$, and $o$-phenylendiamine (Dako, Glostrup, Denmark) were used to develop the reaction. The reaction was stopped by the addition of $150 \mu \mathrm{l} /$ well $1 \mathrm{M} \mathrm{H}_{2} \mathrm{SO}_{4}$ and the intensity was measured within $1 \mathrm{~h}$ on an ELISA reader at $\mathrm{OD}_{492}$.

Measurement of insulin was performed by an ELISA method (developed by $\mathrm{M}$ Deckert and $\mathrm{T}$ MandrupPoulsen, Steno Diabetes Centre, Gentofte). NuncImmuno Plates Maxi Sorp F96 were used. In each step $130 \mu \mathrm{l}$ reagent /well were added and the plate was washed four times with $400 \mu \mathrm{l} /$ well of washing buffer $(0 \cdot 15 \mathrm{M}$ $\mathrm{NaCl}$ and $0.05 \%$ Tween-20) in a washing machine (Denley Wellwash 4, Denley Instruments Inc., Durham, NC, USA) after each step. The plate was coated with rabbit anti-guinea pig $\operatorname{IgG}$ (Dako) diluted 1:1000 in 
coating buffer, $\mathrm{pH} 9 \cdot 8\left(0.1 \mathrm{M} \mathrm{NaHCO}_{3}\right)$ and afterwards placed for $2 \mathrm{~h}$ at RT and washed. As capturing antibodies, guinea pig anti-pig insulin serum (GPapInsulin) $(10 \mu \mathrm{g} /$ $\mathrm{ml}$ ) (Novo Nordisk) diluted 1:100 000 in dilution buffer $\left(0 \cdot 1 \mathrm{M} \mathrm{NaCl}, \quad 7 \cdot 61 \mathrm{mM} \quad \mathrm{NaH}_{2} \mathrm{PO}_{4} \cdot \mathrm{H}_{2} \mathrm{O}, \quad 32 \cdot 42 \mathrm{mM}\right.$ $\mathrm{Na}_{2} \mathrm{HPO}_{4} \cdot 2 \mathrm{H}_{2} \mathrm{O}, 0 \cdot 1 \%$ Tween-20 pH $7 \cdot 4,0 \cdot 5 \% \mathrm{BSA}$ ) were used, incubated for $2 \mathrm{~h}$ at RT and washed. The third layer consisted of $100 \mu \mathrm{l} /$ well of samples and $30 \mu \mathrm{l} /$ well peroxidase-conjugated insulin (diluted 1:10 000) (Sigma) all diluted in dilution buffer. Incubation was done for $2 \mathrm{~h}$ at RT on a horizontal shaker $(400 / \mathrm{min})$ and washed. For development, tetra-methylbenzidine substrate (Kirkegaard \& Perry Laboratories, Gaithersburg, MD, USA) was added. The development was performed for 20-30 $\mathrm{min}$ in the dark at $\mathrm{RT}$. The reaction was stopped with $1 \mathrm{M}$ $\mathrm{H}_{3} \mathrm{PO}_{4}$ and intensity was measured within $1 \mathrm{~h}$ on an ELISA reader at $\mathrm{OD}_{450}$.

Monolayer cultures of $\beta$-cells and 5-bromo-2'-deoxyuridine (BrdU) labelling

Monolayer cultures of islet cells followed by double staining for BrdU and insulin were prepared essentially as previously described (Nielsen et al. 1989). Briefly, islets were pre-cultured for 5-7 days in RPMI 1640 containing $0.5 \% \mathrm{HS}$, and were then dispersed into single cells by trypsin-EDTA treatment. The cells $(75000)$ were plated in $9 \mathrm{~cm}^{2}$ plastic cell culture slide flasks (Nunc) pre-coated with E-C-L Cell Attachment matrix (Trichem Aps, Virum, Denmark). Two millilitres per flask of RPMI 1640 medium containing $2 \% \mathrm{HS}$ and $0.5 \mu \mathrm{g} / \mathrm{ml} \mathrm{hGH}$ were added. The cells were allowed to attach and establish a monolayer for 7 days, after which they were washed twice in medium without hGH and then cultured for $48 \mathrm{~h}$ in RPMI 1640 containing 2\% HS in the absence or presence of the agent to be tested. Ninety minutes prior to fixation the cells were labelled with $10 \mu \mathrm{M}$ BrdU. The cells were washed twice in RPMI 1640 without serum before fixation in $1 \%$ paraformaldehyde in $0.1 \mathrm{M}$ phosphate buffer $\mathrm{pH} 7 \cdot 4$. The cells were exposed to $1.5 \mathrm{M}$ $\mathrm{HCl}$ for $30 \mathrm{~min}$ and washed. They were incubated with a monoclonal mouse antibody to BrdU (\#M0744; Dako) diluted 1:50 and with GPapInsulin diluted 1:500. The antibodies were visualized by a Texas Red (TR)conjugated goat anti-mouse IgG (\#115-075-100; Jackson Immuno Research, West Grove, PA, USA) and fluorescein isothiocyanate (FITC)-conjugated goat anti-guinea pig IgG (\#106-095-003; Jackson Immuno Research) both diluted 1:100. Dilution of the antibodies was performed in PBS with $0 \cdot 3 \%$ Triton X-100 and $0 \cdot 1 \%$ human serum albumin. The slides were mounted in $20 \%$ glycerol/ $0.05 \mathrm{M}$ Trisma base adjusted to $\mathrm{pH} 8.4$ and stored at $4{ }^{\circ} \mathrm{C}$.

\section{Immunocytochemistry}

Islets from newborn rats were dispersed into single $\beta$-cells and cultured, fixed and stained as described. However, in addition to the primary antibodies R $\alpha m F A 1$ was added in the dilution 1:100. BrdU antibodies were visualized using a 7-amino-4-methylcoumarin-3-acetic acid (AMCA)conjugated donkey anti-mouse IgG antibody, insulin antibodies were visualized using Cy2-conjugated donkey anti-guinea pig $\operatorname{IgG}$ and FA1 antibodies were visualized using a TR-donkey anti-rabbit IgG antibody. All secondary antibodies were diluted 1:100.

\section{Results}

\section{Biosynthesis and processing of Pref-1}

To investigate the processing of Pref- 1 and FA1 we studied the biosynthesis both in RINm5F cells, stably transfected with hPref-1, and in human islets. The RINm5F cells/islets were pulse labelled with ${ }^{35}$ S-labelled cysteine and methionine for $30 \mathrm{~min}$ and subjected to the chase periods indicated in Figure 1, followed by immunoprecipitation with monospecific RahFA1 and SDS-PAGE. Immunoprecipitation of hPref-1 from cell lysates revealed a $46 \mathrm{kDa}$ band which disappeared with time (Fig. 1A, upper gel). After $0.5 \mathrm{~h}$ chase, two bands could be detected in immunoprecipitates from the medium (Fig. 1A, lower gel). One band at $46 \mathrm{kDa}$ probably corresponds to Pref- 1 and the other band at $\sim 38 \mathrm{kDa}$ corresponds to the released product, FA1. The intensity of the bands increased up to $6 \mathrm{~h}$ of chase. After $24 \mathrm{~h}$ of chase a marked reduction was seen for both bands. Similar results were observed by in vitro translation using reticulocyte lysates, where the expected size of $46 \mathrm{kDa}$ was seen in the presence of the membrane fraction, whereas omission of membranes showed 55 and $38 \mathrm{kDa}$ bands (data not shown).

Figure 1B shows the processing of Pref-1 in human islets. From the cell lysates a band of $\sim 48 \mathrm{kDa}$ was detectable after the pulse period (left side of the panel). After a $5 \mathrm{~h}$ chase period this band decreased in intensity and another band $\sim 20 \mathrm{kDa}$ could now be detected. In the medium, three bands at 55, 28 and $20 \mathrm{kDa}$ were detectable just after the pulse period (right side of the panel). These three bands disappeared after $5 \mathrm{~h}$. In addition, we investigated the processing in neonatal rat islets. These results (data not shown) showed that Pref-1 was detectable in the cell lysates after the pulse period. The size of the band increased after $1 \mathrm{~h}$ of chase, after which it almost disappeared from the lysates. In the medium we observed a band corresponding in size to Pref- 1 . However, this band was not detected during the chase period.

These data suggest that the Pref- 1 is indeed synthesized in $\beta$-cells and that both intact Pref- 1 and cleavage products corresponding to FA1 and smaller fragments are released into the medium. In addition, the turnover of endogenous Pref- 1 appears to be faster than that of the transfected molecule. 
A

\section{Chase hours}

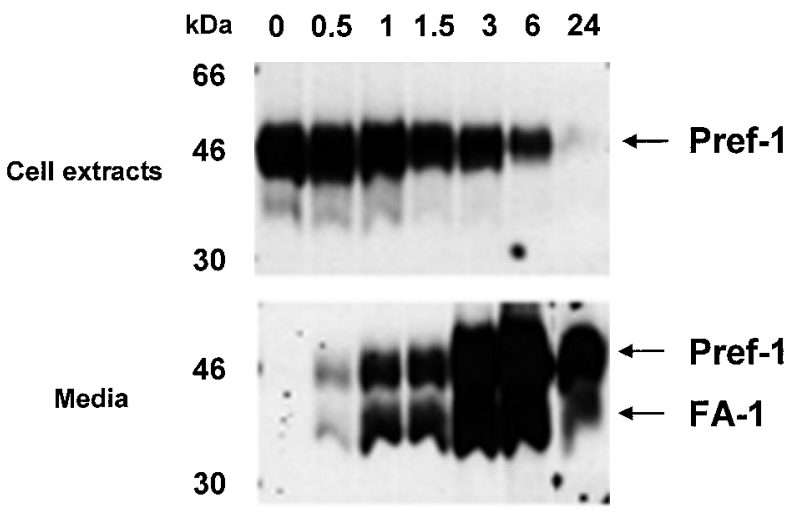

B

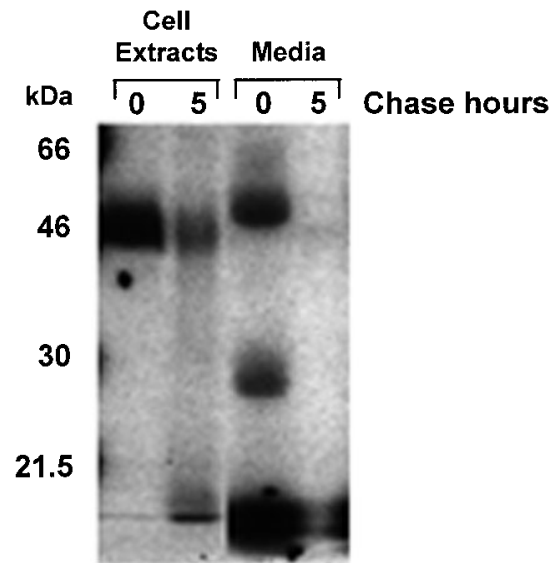

Figure 1 Pref- 1 processing in RINm5F cells stably transfected with hPref- 1 and in human islets investigated by pulse-chase analysis.

(A) The processing of Pref- 1 in RINm5F cells. Upper panel, immunoprecipitation of cellular hPref-1; lower panel, immunoprecipitation of soluble hPref-1/FA1. Molecular mass markers are shown on the left. (B) The processing of Pref- 1 in human islets. Left panel, immunoprecipitation of cellular hPref-1; right panel, immunoprecipitation of soluble hPref-1/FA1.

Molecular mass markers are shown on the left. The figures show representative experiments.

Stimulation of Pref-1 $m R N A$ expression and FA1 release by $b G H$ and oPRL

Since the processing of Pref- 1 indicated FA1 as a cleavage product, and since it has been shown previously that Pref- 1 is regulated by GH and PRL, we wanted to investigate the effect of $\mathrm{bGH}$ and oPRL on Pref- 1 mRNA expression and FA1 release in neonatal rat islets. The islets were cultured up to 7 days in the presence or absence of $1 \mu \mathrm{g} / \mathrm{ml} \mathrm{bGH}$ or oPRL. The mRNA level was measured by quantitative RT-PCR using specific primers for Pref- 1 and G6PDH as an internal control, and the FA1 release
A

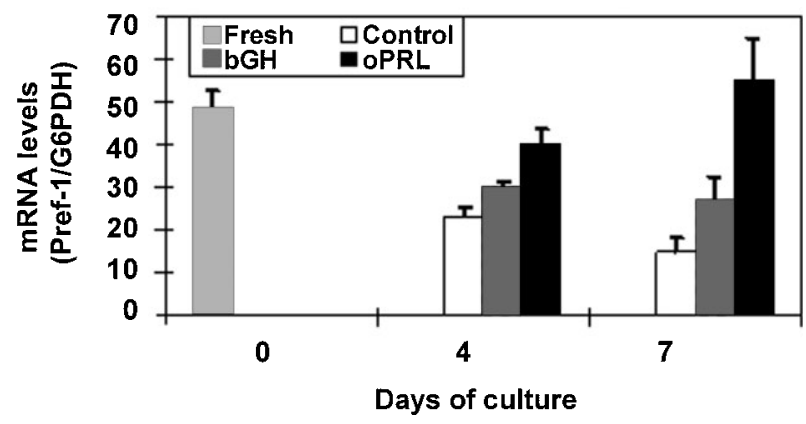

B

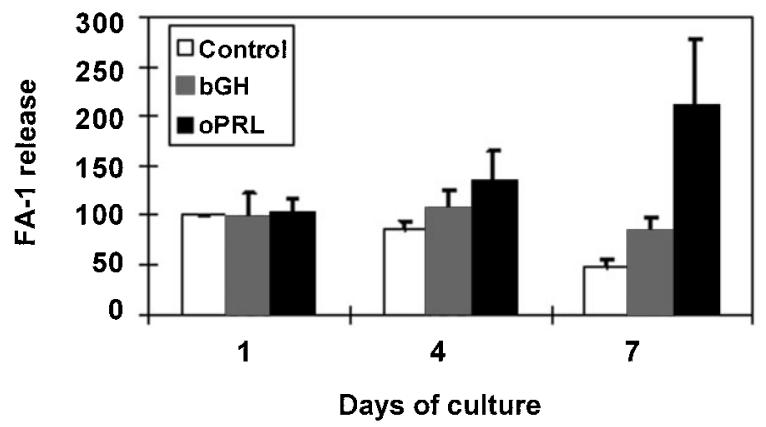

Figure 2 The expression of Pref- 1 mRNA and FA1 release in neonatal rat islets cultured for 1, 4 and 7 days in RPMI 1640 supplemented with $0.5 \% \mathrm{HS}$ and in the absence or presence of either $1 \mu \mathrm{g} / \mathrm{ml}$ bGH or $1 \mu \mathrm{g} / \mathrm{ml}$ oPRL. (A) The Pref- 1 mRNA levels were determined using RT-PCR and expressed as a ratio of G6PDH. (B) The content of FA1 in culture medium was determined by ELISA and expressed as percentage of the FA1 concentration at day 1 . Results are expressed as means \pm S.E.M., $n=4$ or 5 .

was measured by a sandwich ELISA (Jensen et al. 1997). In freshly isolated neonatal islets the level of Pref-1 mRNA was $48 \cdot 4 \pm 7 \cdot 4 \%$ (s.E.M.) (Pref-1/G6PDH) but was found to decrease with time in culture (Fig. 2A). After 7 days of culture the expression had decreased $\sim 65 \%$. However, the addition of both $\mathrm{bGH}$ and oPRL was found to counteract this effect and after 7 days the stimulatory effect of $\mathrm{bGH}$ and oPRL was $1 \cdot 9 \pm 0 \cdot 1$-fold and $4 \cdot 0 \pm 0 \cdot 4$-fold respectively, compared with non-treated islets.

The FA1 content of the culture medium was measured after 1, 4 and 7 days. In medium from non-stimulated islets the concentration of FA1 was $1 \cdot 4 \pm 0.7 \mathrm{ng} / \mathrm{ml}$ after 1 day of culture, decreasing to $0 \cdot 8 \pm 0 \cdot 4 \mathrm{ng} / \mathrm{ml}$ after 7 days of culture (Fig. 2B). At day 7, the FA1 release was significantly increased due to the effect of both bGH and oPRL, $2 \cdot 0 \pm 0 \cdot 4$-fold and $4 \cdot 3 \pm 0 \cdot 7$-fold respectively, compared with non-treated islets.

\section{FA1 and insulin immunoreactivity}

Immunohistochemical studies have indicated that FA1 is co-localized with insulin in the secretory granules (Jensen 
A

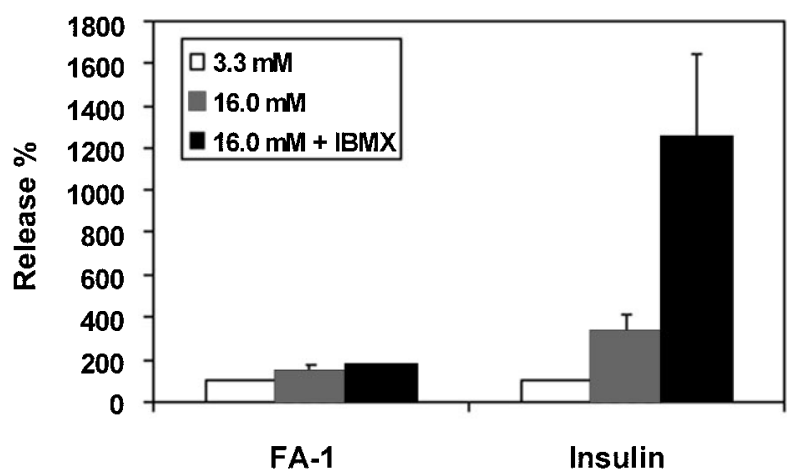

B

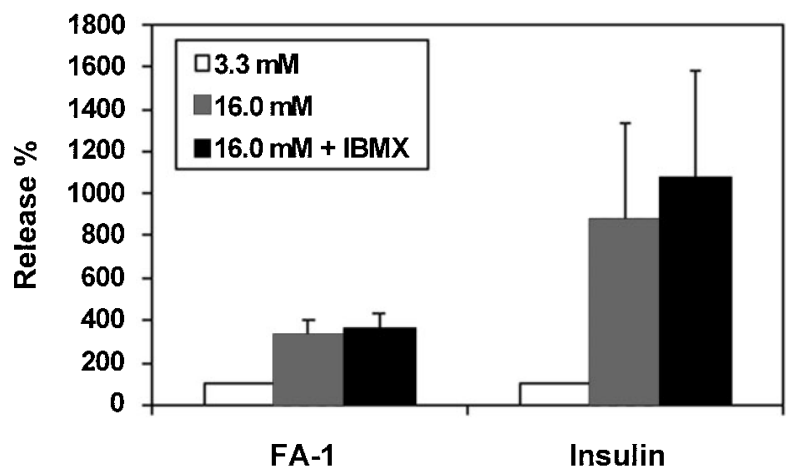

Figure 3 Glucose-stimulated release of FA1 and insulin from neonatal rat islets measured by sandwich ELISA and competitive ELISA respectively. The islets were cultured in RPMI 1640 with $0.5 \% \mathrm{HS}$ and stimulated with either $3.3 \mathrm{mM}$ glucose (basal), $16 \mathrm{mM}$ glucose or $16 \mathrm{mM}$ glucose $+0 \cdot 1 \mathrm{mM}$ IBMX. (A) The release measured after $2 \mathrm{~h}$. (B) The release measured after $48 \mathrm{~h}$. The release is expressed as a percentage of the release from islets cultured with $3.3 \mathrm{mM}$ glucose. Data are means \pm S.E.M., $n=3$.

et al. 1994). To investigate whether FA1 secretion is regulated by glucose and whether FA1 is co-secreted with insulin, neonatal rat islets were cultured for either $2 \mathrm{~h}$ (Fig. $3 \mathrm{~A})$ or 2 days (Fig. 3B) in the presence of physiologically low $(3.3 \mathrm{mM})$ or high $(16 \mathrm{mM})$ glucose concentrations. A parallel incubation with the phosphodiesterase inhibitor 3-isobutyl-1-methylxanthine (IBMX) was included at high glucose to evaluate the FA1 release at maximal insulin secretory activity. The FA1 and insulin content of the culture medium was measured by sandwich ELISA and competitive ELISA respectively. A $2 \mathrm{~h}$ exposure of the islets to $16 \mathrm{mM}$ glucose resulted in a $3 \cdot 3 \pm 0 \cdot 1$-fold increase of the insulin release and a minimal effect was obtained on the FA1 in the same condition, to $1 \cdot 5 \pm 0 \cdot 3$ fold compared with basal. The addition of IBMX further increased the insulin release up to $12.5 \pm 0.9$-fold, whereas no further effect was obtained for FA1 release.
Islets stimulated for $48 \mathrm{~h}$ with glucose exhibited an $8 \cdot 8 \pm 4 \cdot 6$-fold increase of the insulin release and $a$ $3 \cdot 4 \pm 0 \cdot 6$-fold increase of the FA1 release. IBMX had no further effect. These experiments show that FA1 release from the rat islets is regulated by glucose. However, the glucose-induced insulin release profoundly exceeds that of FA1, indicating that FA1 secretion takes place through a different pathway.

\section{The effect of exogenous and endogenous FA1 on $\beta$-cell proliferation}

Since GH/PRL stimulates $\beta$-cell growth and in addition upregulates Pref-1/FA1 expression we wanted to investigate whether FA1 may act as a $\beta$-cell growth factor. We studied the effect of the addition of affinity-purified hFA1 on $\beta$-cell proliferation measured by incorporation of $\mathrm{BrdU}$ as previously described (Nielsen et al. 1989). Islet cells in monolayer culture were grown for 2 days in the absence or presence of hGH $(0 \cdot 2 \mu \mathrm{g} / \mathrm{ml})$, hFA1 $(10 \mu \mathrm{g} / \mathrm{ml})$, or a combination of the two hormones. BrdU was added to the culture media for the last $90 \mathrm{~min}$ of the culture period and insulin- and BrdU-positive cells were visualized by double-immunofluorescence staining. Stimulation with hGH resulted in a $3.5 \pm 1 \cdot 0$-fold increase of BrdUpositive $\beta$-cells, in accord with previous findings (Nielsen et al. 1989, Billestrup \& Nielsen 1991). However, addition of hFA1 alone or in combination with hGH had no effect on the mitotic activity of the $\beta$-cells within the culture period studied (Fig. 4).

Since a potential effect of secreted FA1 might be dependent on other secreted co-factors we wanted to investigate whether GH-induced $\beta$-cell proliferation is dependent on endogenously produced Pref-1/FA1. We therefore exposed $\beta$-cells in monolayer cultures to conditioned medium from islets treated or untreated with hGH. The control medium had no effect, whereas conditioned medium from islets treated with hGH reached a mitotic index of $3.5 \pm 0.6 \%$ (Fig. 4), which was not significantly different from the effect of $0 \cdot 2 \mu \mathrm{g} / \mathrm{ml} \mathrm{hGH}$ alone $(2 \cdot 8 \pm 0 \cdot 8 \%)$. A neutralizing concentration (1:100) of a polyclonal anti-hGH antiserum was found to completely inhibit the mitogenic effect of hGH alone and of the conditioned medium from hGH-treated islets, suggesting that this effect of hGH is not dependent on a secreted factor like FA1.

\section{Cell proliferation rate in stably Pref-1-transfected RINm5F cells}

To test whether overexpression of Pref-1/FA1 affects $\beta$-cell proliferation, we stably transfected RINm5F cells with hPref-1. The estimated proliferation rate was significantly decreased after $72 \mathrm{~h}$ in Pref-1-expressing cells compared with mock-transfected cells; however, no difference was seen during earlier time points (Fig. 5). Thus 


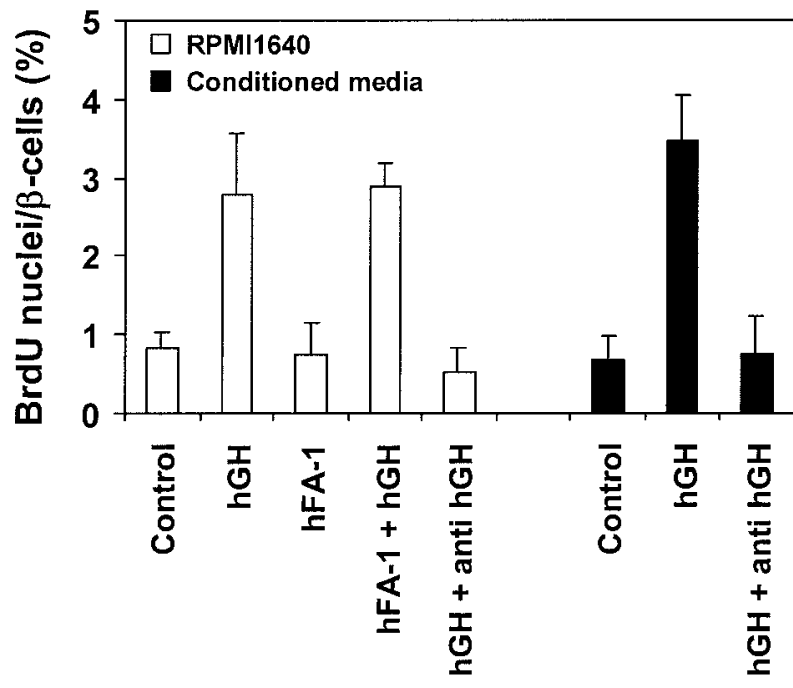

Figure 4 The effect of FA1 on $\beta$-cell mitotic activity. Neonatal rat islet cells in monolayers were cultured for $48 \mathrm{~h}$ in the absence or presence of either $0 \cdot 2 \mu \mathrm{g} / \mathrm{ml} \mathrm{hGH}, 10 \mu \mathrm{g} / \mathrm{ml} \mathrm{hFA} 1$, or a combination of the two or in the presence of conditioned medium (described in Materials and Methods) preincubated or not with anti-hGH antibodies. Cells double-positive for insulin and $\mathrm{BrdU}$ were counted and calculated as a percentage of the total number of insulin-positive cells. Results are means \pm S.E., $n=3$ or 4 .

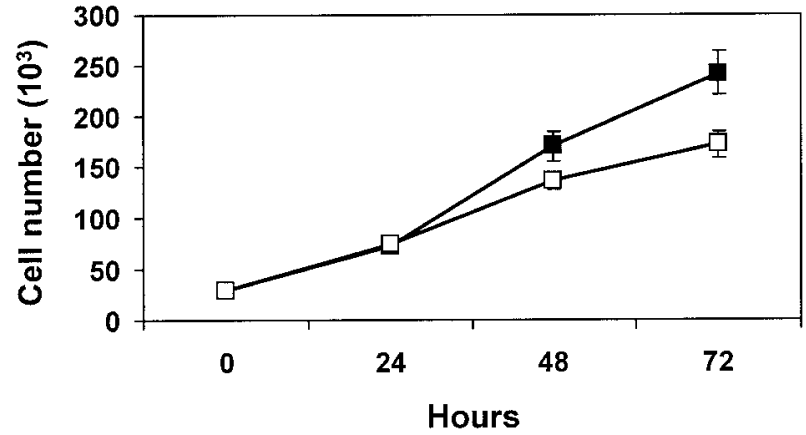

Figure 5 Proliferation rates of RINm5F stably transfected with full-length hPref-1. The proliferation rate was evaluated by plating 30000 cells in 24-well plates and culturing them for $96 \mathrm{~h}$ in RPMI 1640. Cell counts were performed every $24 \mathrm{~h}$ in a Bürker chamber.

increased expression of Pref-1 appears not to stimulate the mitotic activity per se. A significantly lower amount of insulin was detected in the medium from the transfected cells (data not shown). These results are in agreement with the immunocytochemical observations in normal rat $\beta$-cells (Fig. 6).
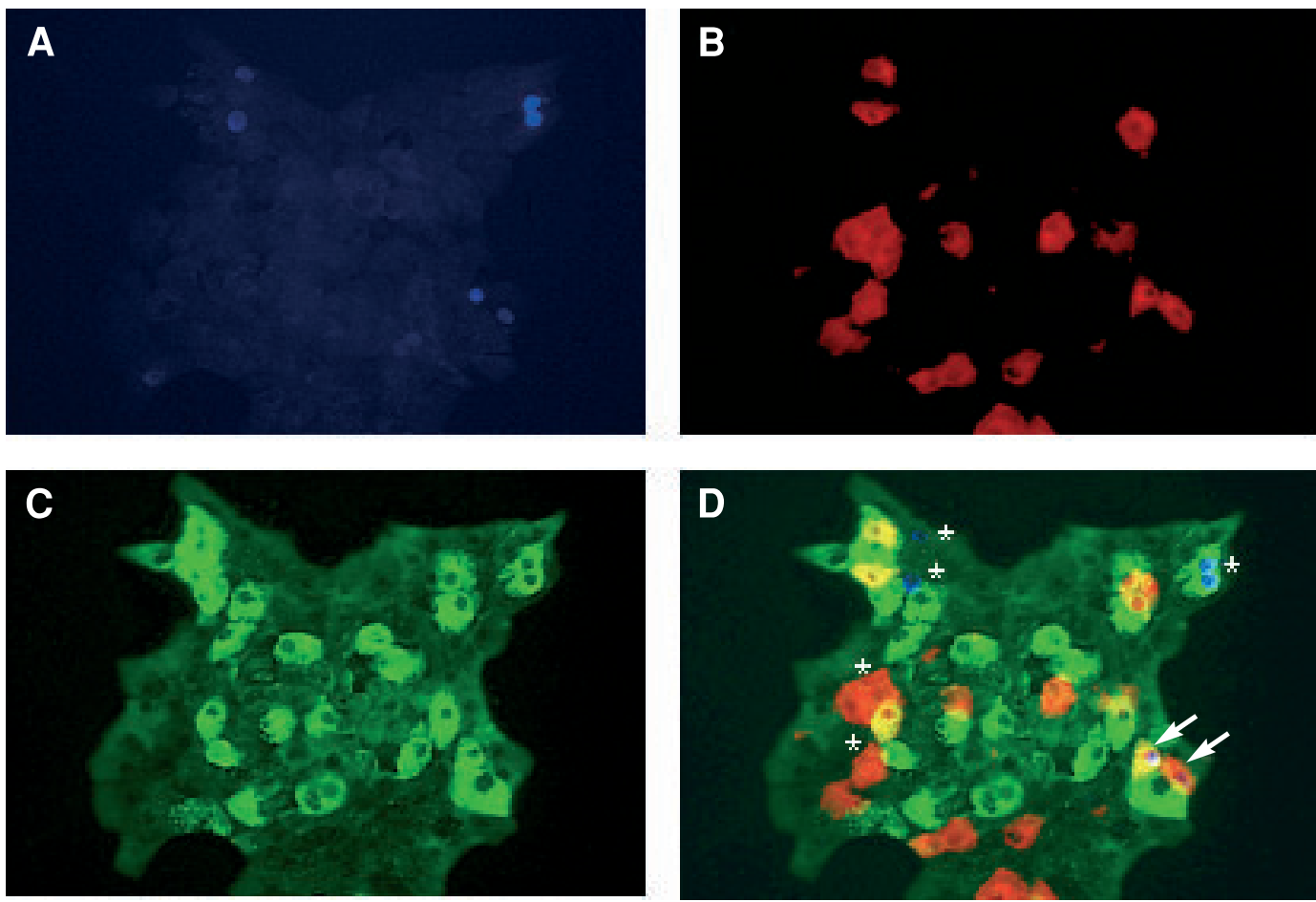

Figure 6 Immunocytochemical detection of FA1/Pref-1, insulin and BrdU in primary $\beta$-cells. Monolayer of dispersed neonatal rat islets triple stained for insulin (green, $\mathrm{Cy}_{2}$ ), Pref-1/FA1 (red, TR) and BrdU (blue, AMCA) immunofluorescence. The section was photographed using single exposure $(A-C)$ and triple exposure (D). The arrows indicate $\beta$-cells that are immunopositive for both Pref- 1 and $\mathrm{BrdU}$ and asterisks indicate $\beta$-cells that are only BrdU-positive or only Pref-1-positive. 


\section{Immunocytochemical localization of Pref-1/FA1 in $\beta$-cell} monolayers

Pref-1/FA1 has previously been found to be expressed in a subpopulation of the $\beta$-cells in the pancreas (Jensen et al. 1993, Tornehave et al. 1993, Carlsson et el. 1997). To evaluate whether Pref-1/FA1 expression defines a population of $\beta$-cells with higher proliferative capacity we investigated the association of Pref-1/FA1 expression and mitotic activity by immunocytochemical staining. $\beta$-Cell monolayers were cultured for 2 days in the presence or absence of hGH $(0 \cdot 2 \mu \mathrm{g} / \mathrm{ml})$. Cells were labelled with BrdU, fixed and stained for BrdU (AMCA - blue fluorescence), FA1 (TR - red fluorescence) and insulin (Cy2green fluorescence). Pref-1/FA1 immunoreactivity was found in only $\sim 20 \%$ of the insulin-positive cells. In addition, no correlation between Pref-1/FA1 expression and mitotic activity was observed, i.e. both Pref-1/FA1positive and Pref-1/FA1-negative cells were found to incorporate $\mathrm{BrdU}$ (Fig. 6), indicating that $\beta$-cells can proliferate without expression of Pref-1/FA1. One characteristic feature was that Pref-1/FA1 expression was mainly observed in cells expressing low levels of insulin. Furthermore, GH did not alter the number of $\beta$-cells expressing Pref-1/FA1, indicating that GH increases the level of Pref-1/FA1 expression in $\beta$-cells already expressing Pref-1/FA1.

\section{Discussion}

In order to characterize the biosynthesis and processing of Pref- 1 in $\beta$-cells we have studied the biosynthesis products by in vitro translation of hPref-1 both in rat insulinoma cells stably transfected with hPref-1 and in normal human islets. The results showed that Pref- 1 is synthesized and processed in both cell types. In the transfected cells the broad band may represent various glycosylated species, splice variants or cleaved forms. In the medium the presence of both the $46-55 \mathrm{kDa}$ and $38 \mathrm{kDa}$ bands may suggest that the long form, which may be membrane-bound or modified, is released, whereas the short form, which may correspond to FA1, is released by proteolytic cleavage, as it is not seen in the cell lysate. Similar results were reported for murine Pref- 1 transfected into COS cells, although both bands are considered as proteolytic cleavage products (Smas et al. 1997). If the membrane-bound form is released into the medium the mechanism remains to be elucidated. The medium from the human islets also showed two forms, a larger form of $55 \mathrm{kDa}$ and a smaller fragment of $28 \mathrm{kDa}$. The exact nature of these forms remains to be determined. The fact that only the full-length protein is found in the cells suggests that the FA1 soluble form is released by proteolytic cleavage on the cell surface. The cleavage sites do not reveal the identity of the enzyme involved (Jensen et al. 1994). Recently it was shown that only the large soluble form of murine Pref-1 corresponding to FA1 is able to inhibit adipocyte differentiation (Mei et al. 2002).

During culture of islets a pronounced decrease in the Pref-1 mRNA level was detected. This could be due to the fact that neonatal islets differentiate to more adult-like cells expressing higher levels of insulin; thereby a decrease in Pref- 1 would be anticipated according to the results shown in Fig. 6. Addition of bGH or oPRL maintained the level of Pref- 1 expression in accord with our previous results (Carlsson et al. 1997). Also the release of FA1 was decreased during culture but increased with the addition of bGH or oPRL. An interesting finding in this context is that the recently cloned Pref- 1 promoter contains a STAT 5 binding element previously described as activated by GH and PRL in $\beta$-cells (Takemori et al. 2001).

The regulation of FA1 release by glucose was moderate after a short exposure, while long-term culture increased the levels of FA1 3-fold. Long-term culture increased insulin 10-fold and was augmented, as expected, by IBMX. This had no effect on FA1 release, indicating that insulin and FA1 are released by different pathways. This is in accord with the inverse correlation between insulin and Pref- 1 content in individual $\beta$-cells as shown in Fig. 6.

Purified FA1 had no effect on the proliferation rate in neonatal rat islet cell monolayers. Conditioned medium from islets cultured for $48 \mathrm{~h}$ with $\mathrm{hGH}$ had the same stimulatory effect as hGH on islets. Proliferation of $\beta$-cells as detected by BrdU incorporation did not correlate with the amount of FA1 present. Stable transfection of RINm5F cells with hPref-1 decreased both their proliferation rate and their insulin content, supporting the idea that Pref-1/FA1 may act as a de-differentiation factor without being a growth factor per se. Recently it has been reported that Pref- 1 attenuates the MAP kinase pathway (Ruiz-Hidalgo et al. 2002) and that Pref-1 interacts with growth arrest-specific protein-1 and acrogranin, which are involved in regulation of cell growth (Baladron et al. 2002). It is, however, striking that the expression of Pref-1 in islets is high during increased mitotic activity of the $\beta$-cells, i.e. in the perinatal period, during pregnancy and by exposure to GH or PRL (Carlsson et al. 1997). It may be speculated that upregulation of Pref- 1 may lead to suppression of certain differentiated functions that may facilitate the responsiveness to mitogenic stimuli in adjacent cells. Such a mechanism has been suggested for haematopoietic stem cells, where Pref-1-expressing stromal cells were found to support self-renewal of the stem cells (Moore et al. 1997). During the embryonic development of the pancreas Pref- 1 is highly expressed in all epithelial cells, but later most of the cells become negative and at birth only the $\beta$-cells are positive (Tornehave et al. 1993, 1996). Hence the early expression of Pref-1 may suppress the differentiation of the endocrine cells while allowing the expansion of their progenitor cells, whereas later, when Pref-1 expression decreases in the 
glandular cells, differentiation to $\beta$-cells proceeds simultaneously with upregulation of Pref- 1 in a subpopulation of these cells. This model is analogous to the cell specification hypothesis for Notch and Delta interactions that is supported by studies of the embryonic development of the endocrine pancreas in Hes-1 mutant mice (Jensen et al. 2000). The signalling pathway may, however, differ, as Pref-1 was able to prevent differentiation of haematopoietic stem cells in these mice (Ohno et al. 2001) although it has been shown that Pref-1 upregulates Hes-1 in immature thymocytes (Kaneta et al. 2000). The possible interactions between the Notch-Delta system and Pref-1 remains to be clarified (Laborda 2000). Interestingly, the null mutation in the Pref- 1 gene was recently shown to result in growth retardation, obesity and increased serum lipid metabolites (Moon et al. 2002), supporting the view that Pref-1, in addition to its possible role in early cell specification, may act as a negative regulator of adipocyte differentiation. How this phenotype relates to the $\beta$-cell function remains to be studied.

In conclusion, the results show that Pref- $1 /$ FA1 is synthesized, processed and released in $\beta$-cells but that it is not directly involved in mediating the mitogenic effect of $\mathrm{GH}$ and PRL. Further studies are needed to determine the role of Pref- 1 in the pancreatic $\beta$-cell.

\section{Acknowledgements}

This study was supported by the Danish Research Academy, the Juvenile Diabetes Research Foundation, the Danish Research Council for Health Sciences, the Danish Diabetes Association, the Novo Nordisk Foundation, the Family Ernfors Fond, the Swedish Diabetes Association, the Swedish Medical Society, Barndiabetesfonden, Magnus Bergvalls stiftelse and the Carlsberg Foundation.

\section{References}

Artavanis-Tsakonas S, Matsuno K \& Fortini ME 1995 Notch signaling. Science 268 225-232.

Bachmann E, Krogh TN, Højrup P, Skjødt K \& Teisner B 1996 Mouse fetal antigen-1 (mfa1), the circulating gene-product of mdlk, pref-1 and scp-1 - isolation, characterization and biology. Journal of Reproduction and Fertility 107 279-285.

Baladron V, Ruiz-Hidalgo MJ, Bonvini E, Gubina E, Notario V \& Laborda J 2002 The EGF-like homeotic protein dlk affects cell growth and interacts with growth-modulating molecules in the yeast two-hybrid system. Biochemical and Biophysical Research Communications 291 193-204.

Billestrup N \& Martin JM 1985 Growth hormone binding to specific receptors stimulates growth and function of cloned insulin-producing rat insulinoma RIN-5AH cells. Endocrinology $1161175-1181$.

Billestrup N \& Nielsen JH 1991 The stimulatory effect of growth hormone, prolactin, and placental lactogen on beta-cell proliferation is not mediated by insulin-like growth factor-I. Endocrinology 129 883-888.

Brelje TC, Scharp DW, Lacy PE, Ogren L, Talamantes F, Robertson M, Friesen HG \& Sorenson RL 1993 Effect of homologous placental lactogens, prolactins, and growth hormones on islet B-cell division and insulin secretion in rat, mouse, and human islets: implication for placental lactogen regulation of islet function during pregnancy. Endocrinology 132 879-887.

Brunstedt J, Nielsen JH \& Lernmark A 1984 Isolation of islets from mice and rats. In Methods in Diabetes Research, pp 245-258. Eds J Larner \& S Pohl. New York: John Wiley and Sons.

Carlsson C, Tornehave D, Lindberg K, Galante P, Billestrup N, Michelsen B, Larsson LI \& Nielsen JH (1997) Growth hormone and prolactin stimulate the expression of rat preadipocyte factor-1/ delta-like protein in pancreatic islets: molecular cloning and expression pattern during development and growth of the endocrine pancreas. Endocrinology 138 3940-3948.

Chomczynski P \& Sacchi N 1987 Single-step method of RNA isolation by acid guanidinium thiocyanate-phenol-chloroform extraction. Annals of Biochemistry 162 156-159.

De W, Breant B, Czernichow P \& Asfari M 1995 Growth hormone $(\mathrm{GH})$ and prolactin (PRL) regulate IGFBP-3 gene expression in rat beta-cells. Molecular Cell Endocrinology 114 43-50.

Fay TN, Jacobs I, Teisner B, Poulsen O, Chapman MG, Stabile I, Bohn H, Westergaard JG \& Grudzinskas JG 1988 Two fetal antigens (FA-1 and FA-2) and endometrial proteins (PP12 and PP14) isolated from amniotic fluid; preliminary observations in fetal and maternal tissues. European Journal of Obstetrics, Gynecology, and Reproductive Biology 29 73-85.

Floridon C, Jensen CH, Thorsen P, Nielsen O, Sunde L, Westergaard JG, Thomsen SG \& Teisner B 2000 Does fetal antigen 1 (FA1) identify cells with regenerative, endocrine and neuroendocrine potentials? A study of FA1 in embryonic, fetal, and placental tissue and in maternal circulation. Differentiation 66 49-59.

Hansen LH, Madsen B, Teisner B, Nielsen JH \& Billestrup N 1998 Characterization of the inhibitory effect of growth hormone on primary preadipocyte differentiation. Molecular Endocrinology 12 1140-1149.

Jensen CH, Teisner B, Højrup P, Rasmussen HB, Madsen OD, Nielsen B \& Skjødt K 1993 Studies on the isolation, structural analysis and tissue localization of fetal antigen 1 and its relation to a human adrenal-specific cDNA, pG2. Human Reproduction $\mathbf{8}$ 635-641.

Jensen CH, Krogh TN, Højrup P, Clausen PP, Skjødt K, Larsson LI, Enghild JJ \& Teisner B 1994 Protein structure of fetal antigen 1 (FA1) - a novel circulating human epidermal-growth-factor-like protein expressed in neuroendocrine tumors and its relation to the gene products of dlk and pG2. European Journal of Biochemistry 225 $83-92$.

Jensen CH, Krogh TN, Støving RK, Holmskov U \& Teisner B 1997 Fetal antigen 1 (FA1), a circulating member of the epidermal growth factor (EGF) superfamily: ELISA development, physiology and metabolism in relation to renal function. Clinica Chimica Acta $2681-20$.

Jensen J, Pedersen EE, Galante P, Hald J, Heller RS, Ishibashi M, Kageyama R, Guillemot F, Serup P \& Madsen OD 2000 Control of endodermal endocrine development by Hes-1. Nature Genetics 24 36-44.

Jensen CH, Meyer M, Schrøder HD, Kliem A, Zimmer J \& Teisner B 2001 Neurons in the monoaminergic nuclei of the rat and human central nervous system express FA1/dlk. Neuroreport 12 3959-3963.

Kaneta M, Osawa M, Sudo K, Nakauchi H, Farr AG \& Takahama Y 2000 A role for pref-1 and HES-1 in thymocyte development. Journal of Immunology 164 256-264.

Laborda J 2000 The role of the epidermal growth factor-like protein dlk in cell differentiation. Histology and Histopathology 15 119-129.

Larsen JB, Jensen CH, Schrøder HD, Teisner B, Bjerre P \& Hagen C 1996 Fetal antigen 1 and growth hormone in pituitary somatotroph cells (letter). Lancet 347191. 
Mei BS, Zhao L, Chen L \& Sul HS 2002 Only the large soluble form of preadipocyte factor-1 (Pref-1), but not the small soluble and membrane forms, inhibits adipocyte differentiation: role of alternative splicing. Biochemical Journal 364 137-144.

Moon YS, Smas CM, Lee K, Villena JA, Kim K, Yun EJ \& Sul HS 2002 Mice lacking paternally expressed Pref-1/Dlk1 display growth retardation and accelerated adiposity. Molecular Cell Biology 22 5585-5592.

Moore KA, Pytowski B, Witte L, Hicklin D \& Lemischka IR 1997 Hematopoietic activity of a stromal cell transmembrane protein containing epidermal growth factor-like repeat motifs. PNAS $\mathbf{9 4}$ 4011-4016.

Nielsen JH 1982 Effects of growth hormone, prolactin, and placental lactogen on insulin content and release, and deoxyribonucleic acid synthesis in cultured pancreatic islets. Endocrinology 110 600-606.

Nielsen JH, Linde S, Welinder BS, Billestrup N \& Madsen OD 1989 Growth hormone is a growth factor for the differentiated pancreatic beta-cell. Molecular Endocrinology 3 165-173.

Ohno N, Izawa A, Hattori M, Kageyama R \& Sudo T 2001 dlk inhibits stem cell factor-induced colony formation of murine hematopoietic progenitors: Hes-1-independent effect. Stem Cells 19 71-79.

Okamoto M, Takemori H, Halder SK, Nonaka Y \& Hatano O 1998 Implication of ZOG protein (zona glomerulosa-specific protein) in zone development of the adrenal cortex. Endocrine Research 24 515-520.

Ruiz-Hidalgo MJ, Gubina E, Tull L, Baladron V \& Laborda J 2002 dlk modulates mitogen-activated protein kinase signaling to allow or prevent differentiation. Experimental Cell Research 274 $178-188$.

Sekine N, Ullrich S, Regazzi R, Pralong WF \& Wollheim CB 1996 Postreceptor signaling of growth-hormone and prolactin and their effects in the differentiated insulin-secreting cell-line, ins-1. Endocrinology 137 1841-1850.

Smas CM \& Sul HS 1993 Pref-1, a protein containing EGF-like repeats, inhibits adipocyte differentiation. Cell 73 725-734.

Smas CM, Chen L \& Sul HS 1997 Cleavage of membrane-associated pref-1 generates a soluble inhibitor of adipocyte differentiation. Molecular Cell Biology 17 977-988.

Sorenson RL \& Brelje TC 1997 Adaptation of islets of Langerhans to pregnancy: beta-cell growth, enhanced insulin secretion and the role of lactogenic hormones. Hormone and Metabolic Research 29 301-307.

Takemori H, Doi J, Katoh Y, Halder SK, Lin XZ, Horike N, Hatano O \& Okamoto M 2001 Characterization of a proximal element in the rat preadipocyte factor-1 (Pref-1) gene promoter. European Journal of Biochemistry 268 205-217.

Tornehave D, Fay TN, Teisner B, Chemnitz J, Westergaard JG \& Grudzinskas JG 1989 Two fetal antigens (FA-1 and FA-2) and endometrial proteins (PP12 and PP14) isolated from amniotic fluid: localisation in the fetus and adult female genital tract. European Journal of Obstetrics, Gynecology, and Reproductive Biology 30 221-232.

Tornehave D, Jansen P, Teisner B, Rasmussen HB, Chemnitz J \& Moscoso G 1993 Fetal antigen 1 (FA1) in the human pancreas: cell type expression, topological and quantitative variations during development. Anatomy and Embryology 187 335-341.

Tornehave D, Jensen CH, Teisner B \& Larsson LI 1996 FA1 immunoreactivity in endocrine tumours and during development of the human fetal pancreas; negative correlation with glucagon expression. Histochemistry and Cell Biology 106 535-542.

Received in final form 28 October 2002 Accepted 31 October 2002 